\title{
Partisipasi Masyarakat Dalam Pembentukan Peraturan Daerah
}

\author{
Praptanugraha \\ Fakultas Hukum Universitas Islam Indonesia \\ e-mail : graha@yahoo.com
}

\begin{abstract}
Public's participation in the process of legislation of local government ordinances is an important aspect for the sake of accommodating and representing public's interest. Moreover, the said participation is also considered as a reflection of the justice and fairness.
\end{abstract}

Key words: Public's Participation, Legislation Process Of Local Ordinances

\section{Pendahuluan}

Melalui kebijakan otonomi daerah yang diatur dalam UU No. 32 Tahun 2004 tentang Pemerintahan Daerah, daerah diberi kewenangan dan tanggung jawab untuk mengatur dan mengurus kepentingan masyarakat setempat menurut prakarsa sendiri berdasarkan aspirasi masyarakat sesuai dengan peraturan perundang-undangan. Melalui kewenangan yang dimilikinya untuk mengatur dan mengurus kepentingan masyarakat, pemerintah daerah akan berupaya untuk meningkatkan perekonomian sesuai dengan kondisi, kebutuhan dan kemampuan yang dimiliki, sehingga memberikan peluang dan kesempatan bagi daerah untuk berupaya semaksimal mungkin dalam rangka mencapai tujuan untuk peningkatan kesejahteraan rakyat di daerah. Dengan adanya otonomi daerah tersebut berarti pemerintah daerah harus berusaha dan mampu mengembangkan diri, menggali potensi untuk kesejahteraan warganya dan sekaligus mempertanggungjawabkan atas pelaksanaan otonomi di daerah.

Dalam rangka mencapai tujuan untuk meningkatkan kesejahteraan tersebut pemerintah daerah mempunyai kewenangan membuat kebijakan dalam rangka memberikan pelayanan, peningkatan peran serta, prakarsa dan pemberdayaan masyarakat. Pengambilan kebijakan ini tentunya akan 
lebih dapat mengakomodir aspirasi masyarakat, karena adanya otonomi daerah semakin mendekatkan jarak antara pengambil keputusan dengan masyarakat. Dengan demikian pemerintah daerah otonom dapat lebih cepat dalam merespon tuntutan masyarakat daerah sesuai dengan kemampuan yang dimiliki. Hal tersebut juga merupakan penghormatan sekaligus pengakuan terhadap keanekaragaman daerah, baik itu suku bangsa, agama, nilai-nilai sosial dan budaya serta potensi lainnya yang terkandung di daerah.

Kewenangan yang diberikan kepada daerah khususnya dalam hal membuat peraturan perundang-undangan dalam hal ini Peraturan Daerah (Perda), selama ini terasa ditanggapi secara berlebihan. Pemerintah daerah berlomba-lomba membuat peraturan daerah sesuai keinginan daerah tanpa memperhatikan ketentuan aturan yang lebih tinggi maupun kepentingan masyarakat umum, sehingga ratusan peraturan daerah yang masuk ke pemerintah pusat dinyatakan bermasalah, bahkan banyak peraturan daerah yang dibuat hanya untuk kepentingan memasukkan pendapatan asli daerah semata, sehingga memberatkan masyarakat. Selain itu banyak perda yang tidak dapat secara optimal dapat diimplementasikan dan ada banyak perda yang diprotes oleh warganya sendiri karena tidak sesuai dengan aspirasi masyarakat bahkan sampai pada tingkat judicial review ke Mahkamah Agung. Sudah menjadi pengetahuan umum bahwa partisipasi masyarakat dalam pembuatan kebijakan publik, baik penyediaan barang dan jasa maupun regulasi, sangat diperlukan. Hal ini untuk menjamin bahwa kebijakan yang disusun akan mengakomodir kepentingan masyarakat serta tidak akan merugikan. Namun sampai saat ini masyarakat belum dapat berpartisipasi secara penuh. Hasilnya dapat dilihat dari masih banyaknya kebijakan publik di daerah yang belum berpihak pada kepentingan masyarakat.

Menurut Undang-Undang Nomor 10 Tahun 2004 tentang Pembentukan Peraturan Perundang-Undangan materi muatan peraturan daerah adalah seluruh materi dalam rangka penyelenggaraan otonomi daerah dan tugas pembantuan, dan menampung kondisi khusus daerah serta penjabaran lebih lanjut peraturan perundang-undangan. yang lebih tinggi.

Usaha untuk mempengaruhi kebijakan publik daerah agar lebih berpihak pada masyarakat telah diusahakan oleh banyak pihak. Salah satu diantara usaha-usaha tersebut adalah melalui advokasi untuk mereformasi regulasi daerah. Dengan adanya advokasi di tingkatan regulasi daerah diharapkan adanya pelembagaan kebijakan publik yang lebih pro-rakyat. 
Usaha untuk mereformasi regulasi di daerah yang partisipatif masih menghadapi banyak kendala, seperti misalnya konflik kepentingan, lemahnya kapasitas berjejaring, pengetahuan hukum, keterbatasan pengetahuan akan substansi yang diadvokasikan, dan lain-lain. Kendala terbesar yang dihadapi sampai saat ini adalah belum secara tegas diatur tentang keharusan adanya partisipasi masyarakat dalam proses penyusunan peraturan daerah. Partisipasi masyarakat dalam proses penyusunan peraturan daerah saat ini masih harus mengandalkan "kesadaran dan kebaikan hati" para birokrat pemerintahan dan anggota DPRD.

Advokasi kebijakan publik yang lebih pro-rakyat melalui penyusunan peraturan daerah harus terus diupayakan agar hasil kebijakan nantinya dapat mencerminkan tuntutan masyarakat serta memenuhi rasa keadilan. Ketiadaan ruang yang jelas bagi partisipasi masyarakat dalam proses penyusunan peraturan daerah tentu saja akan memperbesar resiko adanya penyimpangan dalam substansi yang diusulkan, digagas oleh aparat birokrasi bersama dengan DPRD dengan aspirasi masyarakat. Untuk itu, partisipasi masyarakat harus dilibatkan dalam proses pembentukan peraturan daerah.

Munculnya Peraturan Daerah Kabupaten Bantul Nomor 6 Tahun 2007 tentang Pengawasan, Pengendalian, Pengedaran, dan Pelarangan Penjualan Minuman Beralkohol di Kabupaten Bantul, dapat dijadikan sebagai contoh suatu produk hukum yang sangat menarik karena materi yang diatur banyak bersentuhan dengan kehidupan masyarakat, dan selama ini tidak banyak kita temukan aturan yang tegas dan komprehensip terhadap keberadaan minuman beralkohol. Di samping itu dalam judul peraturan daerah tersebut terdapat kata pelarangan penjualan minuman beralkohol, dimana terhadap pelarangan ini tidak ada yang secara khusus diatribusikan oleh aturan perundang-undangan yang lebih tinggi sebagai acuan dasar ditetapkannya peraturan daerah ini.

Pengaturan keberadaan minuman beralkohol kalau ditinjau dari latar belakang wilayah Bantul memang sangat dilematis, di mana Kabupaten Bantul sektor parawisata merupakan salah satu andalan dalam pemasukan pendapatan asli daerah, sehingga tentu akan berusaha semaksimal mungkin untuk meningkatkan daya dukung wisata. Sedang minuman beralkohol selama ini kita ketahui sangat dekat keberadaan dan dukungannya dalam kehidupan kepariwisataan. Di sisi lain, Kabupaten Bantul yang mempunyai visi Projotamansari. Demokratis, Sejahtera dan 
Agamis ini mempunyai kewajiban untuk mewujudkan visinya, salah satunya bagaimana mewujudkan wilayah yang agamis. Berbicara tentang agamis ini tentunya tidak lepas dengan bagaimana pandangan agama terhadap keberadaan minuman beralkohol. Secara umum dalam norma agama ada ketentuan yang melarang minuman tersebut untuk dinikmati.

Di wilayah Kabupaten Bantul disinyalir banyak beredar minuman beralkohol produk pabrikan ataupun produk tradisional masyarakat, dan lokasi penyebarannya ada di sekitar objek wisata pantai, maupun warungwarung yang secara ilegal menjual minuman tersebut. Hal ini dapat dilihat pada saat berulang kali dilakukan razia baik yang dilakukan oleh Polisi maupun Satuan Polisi Pamong Praja dengan sasaran di tempat objek wisata pantai maupun warung di lingkungan pemukiman penduduk terjaring ratusan bahkan ribuan botol minuman beralkohol. Setiap menjelang bulan puasa Ramadhan hampir pasti diadakan pemusnahan ribuan minuman beralkohol hasil sitaan razia aparat. Bahkan berulang kali razia yang dilakukan oleh aparat tidak ada efek jera bagi pengedar minuman beralkohol ini.

Melihat fakta di lapangan tersebut mengundang permasalahan tersendiri, di tengah-tengah keprihatinan akan kemerosotan moral generasi muda, di dalam proses mewujudkan masyarakat yang agamis, namun merebak dijumpai penjualan minuman keras beralkohol, dan biasanya kehidupan dalam masyarakat yang biasanya mengkonsumsi minuman ini berangkaian dengan tindakan-tindakan yang kurang menyenangkan dalam masyarakat bahkan terkadang menjurus kriminal. Hal tersebut tentu sangat meresahkan, sedangkan dari sisi peraturan belum ada yang mengatur secara lebih rinci dan tegas tentang penjualan minuman beralkohol.

Kondisi demikian terkadang menimbulkan konflik baru dalam masyarakat, dimana ada sekelompok masyarakat yang melakukan razia tersendiri dikarenakan makin banyaknya keberadaan minuman beralkohol, ataupun akibat ketidakpuasaan atas penanganan aparat penegak hukum terhadap pelaku pengedaran minuman beralkohol. Adanya razia sekelompok masyarakat ini tentunya menimbulkan kerawanan, yang bisa memicu konflik antara kelompok yang pro maupun yang kontra.

Dari berbagai permasalahan dan fakta tersebut di atas kiranya sudah tepat apabila Pemerintah Kabupaten Bantul membuat Peraturan Daerah yang materinya terkait dengan minuman beralkohol, sebagai upaya untuk 
melindungi masyarakat dari kemerosotan moral dan penyakit masyarakat lainnya, dan sebagai salah satu upaya untuk mewujudkan visi Kabupaten Bantul.

Berdasarkan uraian diatas, permasalahan yang akan dikaji dalam tulisan ini adalah apa urgensi partisipasi masyarakat dalam pembentukan peraturan daerah.

\section{Pembentukan Peraturan Daerah yang Partisipatif}

\section{Negara Hukum Demokratis}

Negara yang baik menurut Aristoteles ialah negara yang diperintah dengan konstitusi dan berkedaulatan hukum. Ada tiga unsur dari pemerintahan yang berkonstitusi yaitu; pertama pemerintahan dilaksanakan untuk kepentingan umum; kedua pemerintahan dilaksanakan menurut hukum yang beradasarkan pada ketentuan-ketentuan umum, bukan hukum yang dibuat secara sewenang-wenang yang menyampingkan konvensi dan konstitusi; ketiga pemerintahan berkonstitusi berarti pemerintahan yang dilaksanakan atas kehendak rakyat, bukan berupa paksaan-paksaan yang dilaksanakan pemerintah despotik. ${ }^{1}$

Menurut paham Julius Stahl pokok-pokok utama negara hukum yang mendasari konsep negara hukum yang demokratis ialah: ${ }^{2} 1$. berdasarkan hak asasi sesuai pandangan individualistik; 2 . untuk melindungi hak asasi perlu trias politica Montesquieu dengan segala variasi perkembangannnya; 3 . pemerintah berdasarkan undang-undang(wetmatig bestuur) dalam Rechtsstaat materiil dan ditambah prinsip doelmatig bestuur di dalam Sociale verzorgingsstaat; 4 . apabila di dalam menjalankan pemerintahan masih dirasa melanggar hak asasi maka harus diadili dengan suatu pengadilan administrasi.

Sedangkan AV. Dicey seorang pemikir Inggris mengemukakan bahwa terdapat tiga unsur utama pemerintahan yang kekuasaannya dibawah hukum (the rule of law), yaitu: ${ }^{3} 1$. Supremacy of law, artinya bahwa yang mempunyai kekuasaan tertinggi didalam Negara adalah hukum

\footnotetext{
${ }^{1}$ Ridwan HR, Hukum Administrasi Negara, PT Rajagrafindo Persada, Jakarta, 2007, hlm. 9-10

2 Padmo Wahyono, "Asas Negara Hukum dan Perwujudannya dalam Sistem Hukum Nasional" dalam Politik Pembangunan Hukum Nasional, Penyunting Muh. Busyro Muqoddas, dkk, UII Press, Yogyakarta, 1992, hlm,40-41.

${ }^{3}$ Dahlan Thaib, Kedaulatan Rakyat, Negara Hukum, dan Konstitusi, Penerbit Liberty Yogyakarta 1999, hlm 24
} 
(kedaulatan hukum); 2. Equality before the Law, artinya persamaan dalam kedudukan hukum bagi semua warga negara, baik selaku pribadi maupum dalam kualifikasinya sebagai pejabat Negara; 3. Constitution based on individual rights, artinya konstitusi itu tidak merupakan sumber dari hak-hak asasi manusia dan jika hak asasi manusia itu diletakkan dalam konstitusi itu hanya sebagai penegasan bahwa hak asasi manusia itu harus dilindungi.

Menurut Sri Sumantri bahwa unsur-unsur penting negara hukum, yaitu; ${ }^{4} 1$. bahwa pemerintah dalam melaksanakan tugas dan kewajibannya harus berdasarkan atas hukum; 2 . adanya jaminan terhadap hak-hak asasi manusia(warga); 3. adanya pembagian kekuasaan dalam negara; 4 . adanya pengawasan dan badan-badan peradilan (rechterlighe controle).

Dalam kerangka the rule of law diyakini adanya pengakuan bahwa hukum itu mempunyai kedudukan tertinggi, adanya persamaan dalam hukum dan pemerintahan serta berlakunya asas legalitas dalam segala bentuknya dalam kenyataan praktek. Namun demikian, harus ada jaminan bahwa hukum itu sendiri dibangun dan ditegakkan menurut prinsip-prinsip demokrasi, karena prinsip supremasi hukum dan kedaulatan hukum itu sendiri pada pokoknya berasal dari kedaulatan rakyat. Oleh sebab itu, prinsip negara hukum hendaklah dibangun daan dikembangkan menurut prinsip-prinsip demokrasi atau kedaulatan rakyat. ${ }^{5}$

Secara epistimologi, asal kata demokrasi berasal dari bahasa latin, yakni demos, yang artinya rakyat dan kratos, yang artinya pemerintahan. Sehingga dapat diartikan bahwa demokrasi artinya pemerintahan rakyat. ${ }^{6}$ Menurut Baharuddin lopa ${ }^{7}$ bahwa pada dasarnya makna demokrasi ialah pemerintahan yang berdasarkan kehendak rakyat, kedaulatan rakyat. Untuk mewujudkan kehendak tersebut, terlebih dahulu harus dijamin hak persamaan dan hak kebebasan.

Menurut J.B.J.M ten Berge seperti dikutip oleh Ridwan HR menyebutkan prinsip-prinsip negara hukum dan prinsip-prinsip demokrasi sebagai berikut: a. Prinsip-prinsip negara hukum: (1) Asas

${ }^{4}$ Khairuddin Tahmid, Demokrasi dan Otonomi Penyelenggaraan Pemerintahan Desa, Seksi Penerbitan Fak. Syariah IAIN Raden Intan, Bandar Lampung, 2004, hlm. 9.

${ }^{5}$ Ibid, hlm. 9

${ }^{6}$ Abdi Yuhana, Sistem Ketatanegaraan Indonesia Pasca Perubahan UUD 11945 Sistem Perwakilan di Indonesia dan Masa Depan MPR RI, Fokus Media, Bandung, 2007, hlm. 34

${ }^{7}$ Baharuddin Lopa, Pertumbuhan Demokrasi Penegakan Hukum dan Perlindungan Hak Asasi Manusia, PT Yarsif Wataampone, Jakarta, 1999, hlm.7 
Legalitas; (2) Perlindungan hak-hak asasi; 3) Pemerintah terikat pada hukum; (4) Monopoli paksaan pemerintah untuk menjamin penegakan hukum; (5) Pengawasan oleh hakim yang merdeka. b. Prinsip-prinsip demokrasi: 1) Perwakilan politik; 2) Pertanggungjawaban politik; 3) Pemancaran kewenangan; 4) Pengawasan dan kontrol; 5) Kejujuran dan keterbukaan pemerintahan untuk umum; 6) Rakyat diberi kemungkinan untuk mengajukan keberatan. ${ }^{8}$

Hampir semua teoretisi- bahkan sejak zaman klasik- selalu menekankan, bahwa sesungguhnya yang berkuasa dalam demokrasi itu adalah rakyat atau demos, populus. Oleh karena itu, selalu ditekankan peranan demos yang senyatanya dalam proses politik yang berjalan. Paling tidak, dalam dua tahap utama: pertama, agenda setting, yaitu tahap untuk memilih masalah apa yang hendak dibahas dan diputuskan; kedua, deciding the outcome, yaitu tahap pengambilan keputusan. ${ }^{9}$

Dengan demikian dalam negara hukum yang demokratis peranan rakyat sangat diperlukan dalam menentukan masalah apa yang akan dibahas dan diputuskan serta berperan dalam pengambilan keputusan.

\section{Fungsi Legislasi di Daerah}

Dalam penyelenggaraan fungsi legislasi di daerah telah terjadi pergeseran yang dulunya pemerintah daerah sesuai peraturan perundangundangan mempunyai kewenangan membentuk peraturan daerah dengan persetujuan DPRD. Namun perkembangan dewasa ini DPRD yang mempunyai kewenangan membentuk peraturan daerah yang dibahas bersama dengan kepala daerah, beberapa peraturan perundangan yang mengatur hal tersebut antara lain; a. Undang-undang Nomor 10 Tahun 2004 tentang Pembentukan Peraturan Perundang-undangan, Pasal 26 disebutkan bahwa rancangan peraturan daerah dapat berasal dari Dewan Perwakilan Rakyat Daerah atau Gubernur atau Bupati/Walikota, masingmasing sebagai kepala pemerintah daerah propinsi, kabupaten atau kota; b. Undang-undang Nomor 32 Tahun 2004 tentang Pemerintahan Daerah, Pasal 41 disebutkan bahwa DPRD memiliki fungsi legislasi, anggaran dan pengawasan. Sedangkan dalam ketentuan Pasal 42 disebutkan bahwa dalam fungsi legislasi DPRD mempunyai tugas dan wewenang: 1).

\footnotetext{
${ }^{8}$ Ridwan HR, Op.Cit., hlm. 9-10

9 Afan Gafar, Politik Indonesia Transsisimenuju Demokrasi, Pustaka Pelajar, Yogyakarta, 2004, hlm.6.
} 
Membentuk Peraturan Daerah yang dibahas dengan kepala daerah untuk mendapat persetujuan bersama; 2) Membahas dan menyetujui rancangan peraturan daerah tentang APBD bersama dengan kepala daerah; 3) Melaksanakan pengawasan terhadap pelaksanaan perda dan peraturan perundang-undangan lainnya, peraturan kepala daerah, APBD, kebijakan pemerintah daerah dalam melaksanakan program pembangunan daerah, dan kerjasama internasional di daerah.; c. Undang-undang Nomor 22 Tahun 2003 tentang Susunan dan Kedudukan MPR, DPR, DPD dan DPRD. 1) Dalam ketentuan Pasal 61 huruf a UU No. 22 Tahun 2003 (untuk DPRD Provinsi) dan Pasal 77 huruf a UU No. 22 Tahun 2003 (untuk DPRD Kabupaten/Kota), DPRD mempunyai fungsi legislasi, anggaran dan pengawasan; 2) Dalam ketentuan Pasal 62 (DPRD Propinsi) dan pasal 78(DPRD Kota/kabupaten) disebutkan bahwa salah satu tugas dan wewenang DPRD adalah membentuk Peraturan Daerah yang dibahas dengan Gubernur atau Bupati/Walikota untuk mendapat persetujuan bersama; 3) dalam ketentuan Pasal 64 (DPRD Propinsi) dan Pasal 80 (DPRD Kabupaten/kota) disebutkan bahwa anggota DPRD mempunyai hak salah satunya adalah mengajukan rancangan peraturan daerah. d. Peraturan Pemerintah Nomor 25 Tahun 2004 tentang Pedoman Penyusunan Peraturan Tata Tertib DPRD. 1) Ketentuan Pasal 95 ayat (1) disebutkan bahwa DPRD memegang kekuasaan membentuk peraturan daerah; 2) Dalam Pasal 19 ayat (1) dan (2) ditegaskan bahwa DPRD selain mempunyai fungsi anggaran dan fungsi pengawasan juga mempunyai fungsi legislasi yang diwujudkan dalam pembentukan Peraturan Daerah bersama Kepala Daerah .

Dari beberapa tinjauan ketentuan peraturan perundangan tersebut di atas, dapat dilihat bahwa DPRD mempunyai wewenang membentuk peraturan daerah yang dibahas bersama Gubernur/Bupati/Walikota untuk mendapatkan persetujuan bersama. Dengan demikian seharusnya DPRD sebagai lembaga maupun anggota DPRD harus optimal dan produktif melahirkan peraturan daerah yang baik sesuai kepentingan dan harapan masyarakat serta memenuhi rasa keadilan masyarakat. Selain hal tersebut DPRD juga mempunyai bisa menentukan sejauhmanakah partisipasi masyarakat akan dilibatkan dalam proses pembentukan peraturan daerah.

Pelaksanaan fungsi legislasi di daerah secara umum dapat dilihat dari bagaimanakah program legislasi di daerah, proses perumusan dan pembahasan kebijakan daerah, produk kebijakan (peraturan daerah) yang 
telah ditetapkan, dan bagaimanakah peraturan daerah tersebut diimplementasikan. Dilihat dari program legislasi daerah yang seharusnya dipunyai oleh pemerintah di daerah, namun pada kenyataannya tidak semua mempunyai. Menurut S. Soelaso ${ }^{10}$ mengatakan bahwa selama ini DPRD propinsi, kabupaten dan kota tidak mempunyai program legislasi daerah. Ada DPRD dan pemerintah daerah yang tanpa naskah akademik bisa membuat peraturan daerah. Melihat kenyataan masih adanya daerah yang belum mempunyai program legislasi daerah tentunya mengundang keprihatinan tersendiri, karena dengan prolegda ini seharusnya akan tergambar jelas arah kebijakan apa yang akan dihasilkan, perda apa yang akan dibahas atau apa yang akan diatur.

\section{Peraturan Daerah}

Sebagai daerah otonom pemerintah daerah berwenang utnuk membuat peraturan daerah guna menyelenggarakan urusan otonomi daerah dan tugas pembantuan. Sesuai Undang-Undang Nomor 10 Tahun 2004 tentang Pembentukan Peraturan Perundang-Undangan, yang dimaksud dengan peraturan daerah adalah peraturan perundangundangan yang dibentuk oleh dewan perwakilan rakyat daerah dengan persetujuan bersama kepala daerah. Peraturan Daerah merupakan penjabaran lebih lanjut dari peraturan perundang-undangan yang lebih tinggi serta merupakan peraturan yang dibuat untuk melaksanakan peraturan perundang-undangan yang ada di atasnya dengan memperhatikan ciri khas masing-masing daerah. Peraturan daerah dilarang bertentangan dengan kepentingan umum, peraturan perundangundangan yang lebih tinggi serta Perda daerah lain. ${ }^{11}$

Menurut Soehino sebagaimana dikutip oleh B. Hestu Cipto Handoyo mengemukakan bahwa materi muatan peraturan daerah meliputi; 1 . Materi-materi atau hal-hal yang memberi beban kepada penduduk, misalnya pajak dan retribusi daerah; 2. Materi-materi atau hal-hal yang mengurangi kebebasan penduduk, misalnya mengadakan laranganlarangan atau kewajiban-kewajiban yang biasanya disertai dengan ancaman atau sanksi pidana; 3. Materi-materi atau hal-hal yang

${ }^{10}$ S.Soelaso adalah Direktur Eksekutif Asosiasi DPRD Kabupaten seluruh Indonesia, dikutip dari Tempo Interaktif, Jakarta.

${ }^{11}$ Suko Waluyo, Otonomi Daerah Dalam Negara Hukum Indonesia, Pembentukan Peraturan Daerah Partisipatif, Faza Media, Jakarta, 2006, hlm. 127 
membatasi hak-hak penduduk misalnya penertiban garis sepadan. 4 . Materi-materi atau hal-hal yang telah ditentukan dalam peraturan perundang-undangan yang sederajat dan tingkatannya lebih tinggi, harus diatur dengan peraturan daerah. ${ }^{12}$

\section{Proses Pembentukan Peraturan Daerah}

Pembentukan peraturan daerah adalah proses pembuatan peraturan daerah yang pada dasarnya dimulai dari perencanaan, pembahasan, teknik penyusunan, perumusan, pembahasan, pengesahan, pengundangan dan penyebarluasan. Dalam mempersiapkan pembahasan dan pengesahan rancangan peraturan daerah menjadi peraturan daerah, harus berpedoman kepada peraturan perundang-undangan. Peraturan daerah akan lebih operasional lagi jika dalam pembentukannya tidak hanya terikat pada asas legalitas sebagaimana dimaksud dalampasal 136147 Undang-Undang nomor 32 tahun 2004, tetapi perlu dilengkapi dengan hasil penelitian yang mendalam terhadap subjek dan objek hukum yang hendak diaturnya, serta diawali dengan pembentukan naskah akademik terlebih dahulu. ${ }^{13}$ Urgensi dari naskah akademik dalam proses pembentukan peraturan daerah antara lain merupakan media nyata bagi partisipasi masyarakat dalam proses pembentukan peraturan daerah, naskah akademik memaparkan alasan-alasan, fakta-fakta dan latar belakang tentang hal-hal yang mendorong disusunnya suatu masalah atau persoalan sehingga sangat penting dan mendesak diatur dalam peraturan daerah, naskah akademik menjelaskan aspek filosofis, aspek sosiologis, aspek yuridis, aspek politis, aspek ekologi aspek ekonomi dan aspek-aspek lainnya yang berkaitan dengan peraturan daerah yang akan dibuat. ${ }^{14}$

Rancangan peraturan daerah dapat diprakarsai oleh Kepala Daerah atau DPRD. Apabila dilihat dari proses pembahasan rancangan peraturan daerah sesuai Peraturan Pemerintah nomor 25 Tahun 2004 dapat diketahui mekanisme pembahasan rancangan peraturan daerah melalui empat tahap sebagai berikut; a. pembicaraan tingkat pertama, meliputi: 1) penjelasan Kepala Daerah dalam rapat Paripurna tentang penyampaian

\footnotetext{
${ }^{12}$ B. Hestu Cipto Handoyo, Prinsip-Prinsip Legal Drafting E Desain Naskah Akademik, Universitas Atmajaya Yogyakarta, 2008, hlm. 128

${ }^{13}$ Suko Waluyo, Op.Cit,.hlm. 127

${ }^{14}$ Mahendra Putra Kurnia, dkk., Pedoman Naskah Akademik Perda Partisipatif, Kreasi Total Media, Yogyakarta, 2007, hlm.71.
} 
rancangan peraturan daerah yang berasal dari Kepala Daerah; 2) Penjelasan dalam Rapat Paripurna oleh pimpinan komisi atau Pimpinan Panitis Khusus terhadap rancangan peraturan daerah dan atau perubahan Peraturan Daerah atas usul prakarsa DPRD. b. pembicaraan tingkat kedua, meliputi: 1) dalam hal Rancangan Peraturan Daerah yang berasal dari Kepala Daerah: a) pemandangan umum dari Fraksi-fraksi terhadap Rancangan Peraturan Daerah yang berasal dari kepala daerah; b) jawaban Kepala Daerah terhadap pemandangan umum fraksi-fraksi. 2) dalam hal Rancangan Peraturan Daerah atas usul DPRD: a) pendapat Kepala Daerah terhadap Rancangan Peraturan Daerah atas usul DPRD; b) jawaban dari fraksi-fraksi terhadap pendapat Kepala Daerah. c. pembicaraan tingkat ketiga meliputi pembahasan dalam rapat Komisi/ Gabungan Komisi atau Rapat Panitia Khusus dilakukan bersama-sama dengan Kepala Daerah atau Pejabat yang ditunjuk; d. pembicaraan tingkat keempat, meliputi: 1) pengambilan keputusan dalam Rapat Paripurna yang didahului dengan: a) laporan hasil pembicaraan tahap ketiga; b) pendapat Akhir Fraksi; c) pengambilan keputusan. 2) penyampaian sambutan Kepala Daerah terhadap pengambilan Keputusan.

\section{Partisipasi Masyarakat dalam Pembentukan Peraturan Daerah}

Titik tolak dari penyusunan peraturan daerah adalah efektivitas dan efisiensi pada masyarakat. Tujuan dasar dari peran serta masyarakat adalah untuk menghasilkan masukan dan persepsi yang berguna dari warga negara dan masyarakat yang berkepentingan (publik inters) dalam rangka meningkatkan kualitas pengambilan keputusan, karena dengan melibatkan masyarakat yang terkena dampak akibat kebijakan dan kelompok kepentingan (interest grups), para pengambil keputusan dapat menangkap pandangan, kebutuhan dan penghargaan dari masyarakat dan kelompok tersebut, untuk kemudian menuangkannya ke dalam satu konsep. ${ }^{15}$

Terkait partisipasi masyarakat dalam pembentukan peraturan perundang-undangan sebagaimana diatur dalam Pasal 10 UndangUndang nomor 10 Tahun 2004, bahwa masyarakat berhak memberikan masukan secara lisan atau tertulis dalam rangka penetapan maupun pembahasan rancangan undang-undang dan rancangan peraturan daerah. Selanjutnya dalam Pasal 39 ayat (1) Undang-Undang 32 Tahun

\footnotetext{
${ }^{15}$ Mahendra Putra Kurnia, dkk., Op.Cit., hlm. 72.
} 
2004 menyatakan bahwa hak masyarakat untuk berpartisipasi dalam memberikan masukan secara lisan atau tertulis dalam rangka pemyiapan atau pembahasan rancangan peraturan daerah.

Partisipasi dimaksudkan sebagai keikutsertaan pihak-pihak luar DPRD dan pemerintah daerah dalam menyusun dan membentuk rancangan peraturan daerah atau Perda. Ada dua sumber partisipasi; pertama dari unsur pemerintahan diluar DPRD dan pemerintah daeraah, seperti polisi, kejaksaan, pengadilan, perguruan tinggi dan lain-lain. Kedua dari masyarakat, baik individual seperti ahli-ahli atau yang memiliki pengalaman atau dari kelompok seperti LSM. Mengikutsertakan pihak-pihak luar DPRD dan pemerintah daerah sangat penting untuk (i) menjaring pengetahuan, keahlian atau pengalaman masyarakat sehingga Perda benar-benar memenuhi syarat peraturan perundang-undangan yang baik; (ii) menjamin Perda sesuai dengan kenyataan yang hidup dalam masyarakat; (iii) menumbuhkan rasa memiliki(sense of belonging), rasa bertanggung jawab atas Perda tersebut. ${ }^{16}$

Menurut Bagir Manan partisipasi dapat dilakukan dengan cara: ${ }^{17}$ (1) mengikut sertakan dalam tim atau kelompok kerja penyusunan Perda.(2) melakukan publik hearing atau mengundang dalam rapat-rapat penyusunan Perda. (3) melakukan uji sahih kepada pihak-pihak tertentu untuk mendapat tanggapan. (4) melakukan loka karya(workshop) atas Raperda sebelum secara resmi dibahas oleh DPRD. (5) mempublikasikan Raperda agar mendapat tanggapan publik.

Dari berbagai uraian di atas untuk membentuk peraturan daerah yang dapat memenuhi aspirasi yang diinginkan masyarakat tentunya harus diimbangi dengan keterlibatan masyarakat, meliputi; (1) Keterlibatan dalam penyusunan rancangan peraturan daerah. Pada tahap ini masyarakat dapat terlibat dalam proses penyusunan dalam tim/kelompok kerja, terlibat dalam penyiapan naskah akademik, maupun penyampaian masukan yang disampaikan secara lisan, tulisan, ataupun melalui media massa ditujukan kepada penggagas peraturan daerah/tim. Adapun yang menjadi kendala adalah sejauhmana transparansi serta komitmen stakeholder terkait, sehingga masyarakat mengetahui dan dapat memberi masukan tentang agenda yang sedang dan akan dibahas. (2) Keterlibatan dalam proses pembahasan peraturan daerah. Proses ini sebagian besar berada pada

${ }^{16}$ Bagir Manan, Menyongsong Fajar Otonomi Daerah, PSH Fak. Hukum UII, Yogyakarta,2001, hlm. 85

${ }^{17} \mathrm{Ibid}, \mathrm{hlm} .85-86$. 
posisi pembahasan antara DPRD dan Pemerintah Daerah. Dalam tahap ini seharusnya sebelum dibahas terlebih dahulu diumumkan di media massa untuk memberi kesempatan kepada masyarakat menyampaikan aspirasinya. Selanjutnya dalam proses pembahasan masyarakat bisa memberikan masukan secara lisan, tertulis ataupun pada saat rapat-rapat pembahasan perda. Terhadap kehadiran dalam rapat memang menjadi dilema, karena hal tersebut tergantung keinginan DPRD maupun pemerintah daerah apakah akan mengundang masyarakat atau membiarkan proses pembahasan berjalan tanpa keterlibatan masyarakat. (3) Keterlibatan pada pelaksanaan peraturan daerah. Keterlibatan masyarakat pada tahap ini bisa terlihat bagaimana masyarakat patuh terhadap materi peraturan daerah karena merasa sudah sesuai aspirasi, atau justru kebalikannya masyarakat merasa dirugikan atau tidak merasa tersalurkan aspirasi. Apabila masyarakat merasa dirugikan dapat menempuh jalur memberikan masukan kepada lembaga pembentuk peraturan perundang-undangan, dan bisa dijadikan sebagai bahan pertimbangan untuk melakukan perubahan ataupun mencabut peraturan tersebut. Selanjutnya juga bisa diambil langkah melalui judicial review. Menurut Ni'matul Huda, ${ }^{18}$ pengaturan judicial review oleh Mahkamah Agung, diatur dalam UU No. 4 Tahun 2004 Pasal 11 ayat (2) huruf b dan ayat (3) yang menegaskan, Mahkamah Agung mempunyai kewenangan menguji peraturan perundang-undangan di bawah undang-undang terhadap undang-undang. Pernyataan tidak berlaku peraturan perundangundangan sebagai hasil pengujian, dapat diambil baik dalam pemeriksaan tingkat kasasi maupun berdasarkan permohonan langsung kepada MA.

Termasuk salah satu kendala dalam mewujudkan peraturan daerah yang partisipatif adalah dari sisi peraturan perundang-undangan memang tidak diatur secara tegas bahwa proses pembentukan peraturan perundang-undangan (peraturan daerah) harus ada partisipasi masyarakat. Dalam Pasal 53 Undang-Undang Nomor 10 Tahun 2004 bahwa masyarakat berhak memberikan masukan secara lisan atau tertulis dalam rangka penetapan maupun pembahasan rancangan undang-undang dan rancangan peraturan daerah. Selanjutnya dalam Undang Undang Nomor 32 Tahun 2004 sebagaimana telah diubah beberapa kali dan perubahan terakhir dengan Undang Undang Nomor

${ }^{18}$ Ni'matul Huda, Negara Hukum, Demokrasi \& Judicial Review, UII Press, Yogyakarta, 2005, hlm. 115 
12 Tahun 2008, Pasal 139 disebutkan bahwa masyarakat berhak memberikan masukan secara lisan atau tertulis dalam rangka penyiapan atau pembahasan rancangan perda.

\section{Penutup}

Semakin majunya perkembangan suatu negara dan semakin kompleksnya permasalahan kehidupan, tentu memerlukan peraturan perundang-undangan yang bisa mengakomodasi dan merepresentasikan kepentingan masyarakat umum, serta mencerminkan rasa keadilan masyarakat. Untuk mewujudkan hal tersebut merupakan tuntutan dan tantangan bagi pembentuk hukum untuk membuat peraturan perundangundangan (peraturan daerah) yang partisipatif.

Peran serta masyarakat akan lebih meningkatkan kualitas keputusan yang dihasilkan dan mendorong para pembentuk hukum untuk membuat peraturan daerah yang implementatif sesuai kebutuhan dan harapan masyarakat dan dapat diminimalisir dari gejolak ataupun tuntutan ketidak puasan masyarakat.

Sehubungan dari sisi peraturan perundang-undangan tidak diatur secara tegas tentang harus dilibatkannya partisipasi masyarakat dalam pembentukan peraturan daerah, maka diperlukan komitmen dari pembentuk hukum di daerah dalam hal ini Kepala Daerah dan DPRD untuk melibatkan masyarakat dalam setiap pembahasan peraturan daerah.

\section{Daftar Pustaka}

Abdi Yuhana, Sistem Ketatanegaraan Indonesia Pasca Perubahan UUD 11945 Sistem Perwakilan di Indonesia dan Masa Depan MPR RI, Fokus Media, Bandung, 2007

Afan Gafar, Politik Indonesia Transsisi Menuju Demokrasi, Pustaka Pelajar, Yogyakarta, 2004.

Baharuddin Lopa, Pertumbuhan Demokrasi Penegakan Hukum dan Perlindungan Hak Asasi Manusia, PT Yarsif Wataampone, Jakarta, 1999.

Bagir Manan, Hubungan Antara Pusat dan Daerah Menurut UUD 1945, Penerbit LSH Jakarta, tahun 1994.

Menyongsong Fajar Otonomi Daerah, PSH FH UII, Yogyakarta, 2001.

B. Hestu Cipto Handoyo, Prinsip-Prinsip Legal Drafting \& Desain Naskah Akademik, Universitas Atmajaya Yogyakarta, 2008, 
Dahlan Thaib, Kedaulatan Rakyat, Negara Hukum, dan Konstitusi, Penerbit Liberty Yogyakarta 1999.

Khairuddin Tahmid, Demokrasi dan Otonomi Penyelenggaraan Pemerintahan Desa, Seksi Penerbitan Fak. Syariah IAIN Raden Intan, Bandar Lampung, 2004.

Mahendra Putra Kurnia, dkk., Pedoman Naskah Akademik Perda Partisipatif, Kreasi Total Media, Yogyakarta, 2007

Ni'matul Huda, Negara Hukum, Demokrasi \& Judicial Review, UII Press, Yogyakarta, 2005.

Padmo Wahyono, "Asas Negara Hukum dan Perwujudannya dalam Sistem Hukum Nasional" dalam Politik Pembangunan Hukum Nasional, Penyunting Muh. Busyro Muqoddas, dkk, UII Press, Yogyakarta, 1992. Ridwan HR, Hukum Administrasi Negara, PT Rajagrafindo Persada, Jakarta, 2007.

Suko Waluyo, Otonomi Daerah Dalam Negara Hukum Indonesia, Pembentukan Peraturan Daerah Partisipatif, Faza Media, Jakarta, 2006. Undang Undang nomor 32 Tahun 2004 tentang Pemerintah Daerah Undang Undang Nomor 10 Tahun 2004 tentang Pembentukan Peraturan Perundang-undangan 